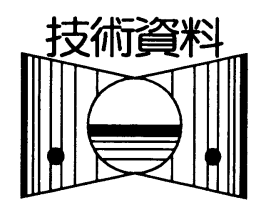

\title{
ディーゼル機関の副燃料噴射による 脱硝装置の特性*
}

\author{
中 山信 義** 神 社 洋 一** \\ 山下尚**菅田雅 裕*** \\ 矢 萩 強 志**** 渡 邊 元 尚****
}

Characteristics of deNOx Equipment using of Fuel Sub-Injection Valve for 4-Stroke Diesel Engine

By Nobuyoshi Nakayama, Yoichi Jinja, Hisashi Yamashita, Masahiro Sugata, Tuyoshi Yahagi, Motohisa Watanabe

In this paper, we report about generation of reduction agent for deNOx equipment used diesel engine. Following tests have been carried out, so that fuel for NOx-agent is used availably. One is investigation of exhaust gas character, in case of fuel addition in the cylinder, and the other is NOx reduction performance test, used the small size deNOx equipment.

As result of experiments, following have been found.

(1). Gaseous hydrocarbon, available NOx reduction is generated by fuel sub-injection.

(2). Sub-injection timing is suitable near BDC, opened exhaust valve.

(3). Reduction rate of deNOx equipment with fuel sub-injection is equivalent one with gaseous agent, and is about $40 \%$.

\section{1. まえがき}

船舶用ディーゼル機関から排出される有害物質 ( $\mathrm{NOx}, \mathrm{SOx}, \mathrm{PM}$ 等) は, 今や地球規模で対処しなけ ればならない問題となってきている。この問題に対し て筆者らは，タイミングリタードや排気再循環 (EGR) などのエンジン内部での改善技術, メタノール, 天 然ガスあるいは水エマルジョン燃料などの前処理技 術, そして触媒を用いた後処理技術などの開発研究 を実施してきた。

後処理技術のひとつとして，炭化水素系還元剤を 用いた脱硝システムの研究1.2)をしてきたが，還元戍 として気体還元剤を用いているためにランニングコ

\footnotetext{
*原稿受付 平成12年1月 20 日

**正会員川崎重工株式会社（明石市川崎町 1-1)

$* * *$ 川崎重工株式会社（明石市川崎町1-1)

$* * * *$ 元・造船業基盤整備事業協会（港区虎八盯3-23-6）
}

ストに占める還元剤の費用が大きく, 実用化のための 障害となっている。このため安価で, 取扱いの容易 な液体還元剤すなわち燃料を使用するための研究 を実施している。

本報では，その一環として実施したディーゼル機 関の燃料の副噴射により生成される還元剤の特性と それを用いた小型脱硝試験装置の脱硝性能につい て報告する。

\section{2. 炭化水素系還元剤を用いた脱硝}

筆者らは，装置の小型化，低ランニングコスト，低 温活性を目指して，脱アンモニア還元剤脱硝として 炭化水素を還元剤とする脱硝システムの研究開発を 実施している。この代表的な船舶用脱硝プラントの 概念罒を罒1に示す。

本システムは炭化水素系還元剤例えば燃料などを 


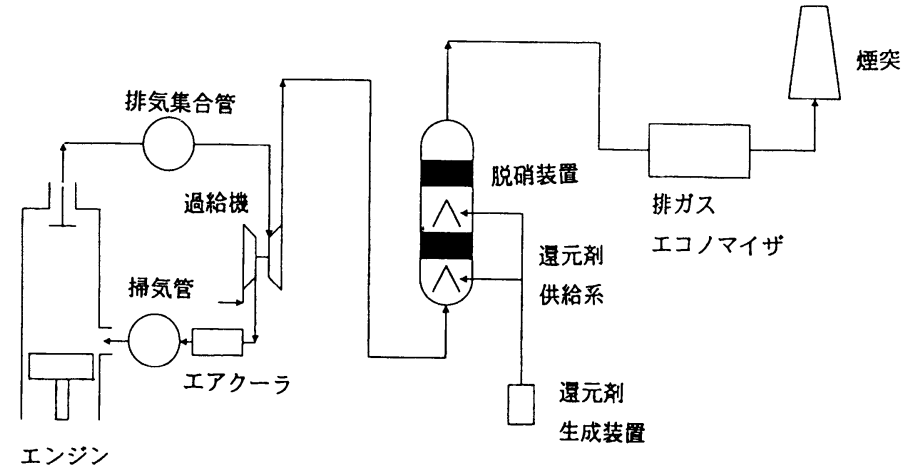

図1 船舶用脱硝プラントの概念系統図

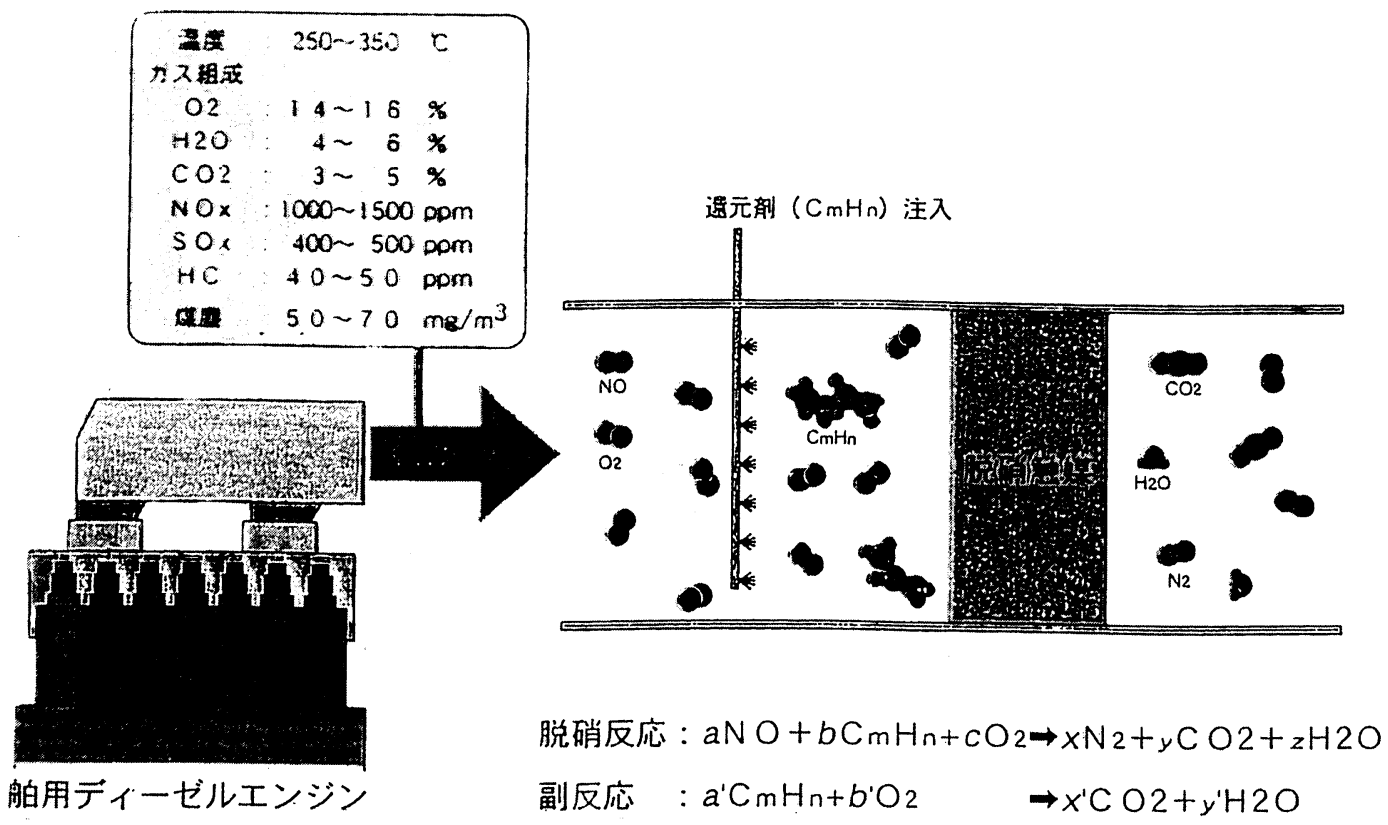

図2 炭化水素系還元剤による脱硝の原理

用いた脱硝装置である. その脱硝原理と基礎特性を 以下に示す。

炭化水素系還元骺を用いた脱硝反応は，次に示 すとおり窒素酸化物 $\left(\mathrm{NO}_{\mathrm{x}}\right)$ が炭化水素 $\left(\mathrm{C}_{\mathrm{m}} \mathrm{H}_{\mathrm{n}}\right)$ によ り無害な窒素 $\left(\mathrm{N}_{2}\right)$ に還元されることを基本としたも のである.

$\left(\mathrm{NOx}, \mathrm{C}_{\mathrm{m}} \mathrm{H}_{\mathrm{n}}, \mathrm{O}_{2}\right) \rightarrow\left(\mathrm{N}_{2}, \mathrm{CO}_{2}, \mathrm{H}_{2} \mathrm{O}\right)$

しかし，この反応は極めて複雑でいくつもの副反 応を伴っており，その反応機構についてはまだ解明 段階にあり, 数多くの説が提唱されている. 図2に脱
硝の説明図を示す.

ここで使用される還元剈としては，低級オレフィン， あるいは炭素数 12 以下のパラフインが有効と言われ ている. また触媒としては，ゼオライト系およびアル ミナ系を中心に検討されている.これらの内，舶用 ディーゼル機関に適用できるものとして，低温活性が あり，耐SOx性にも優れた白金等をイオン交換した ゼオライト系触媒が有望である.

図3，4および5は，筆者らが模擬ガスを使って行 ったベンチテストの結果である. 図3は交換カチオン 


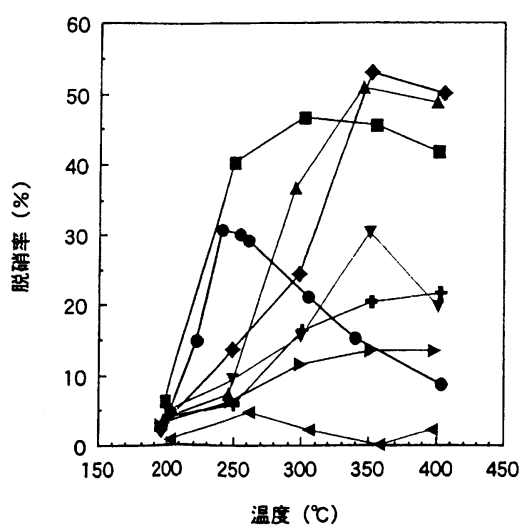

触媒稙

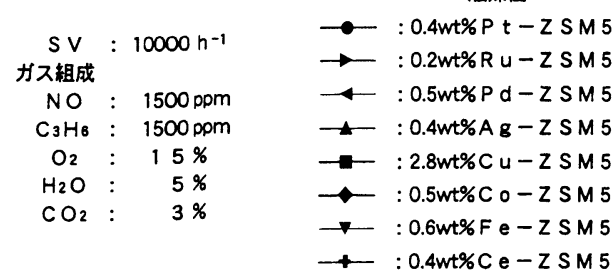

図3 交換カチオンによる脱硝活性の比較 (模擬ガス)

による温度特性を示したものである．低温特性の良 いものとして，CuとPtが挙げられる．特にCuは活性 温度領域も広く, その活性も高いことが分かる. しか し，図4に示すように $\mathrm{SO}_{2}$ による脱硝活性の劣化が 著しく, 舶用ディーゼル機関などのように重質油を燃 焼させた排ガスの脱硝には適さないことが分かる. Pt は $\mathrm{Cu}$ ほど活性は高くないが, 耐 $\mathrm{SO}_{2}$ 性が高いことが 分かる. Pt一ZSM5触媒については, 別途実施した 実排ガスによる長時間の耐久試験でも耐 $\mathrm{SOx}$ 性の高 いことが確認されている. ${ }^{1,2)}$ 図 5は，還元剤種によ る脱硝活性を比較したものである. オレフィン系であ るエチレン，プロピレンは，ほぼ同じ特性を示し， 活性も高いことが分かる.

\section{3. 試験方法}

3.1 試験装置＼cjkstart試験装置は，罒6に示すように 試験機関と脱硝性能試験装置に大別される。試験機 関から排出された燃焼排ガスの一部を脱硝性能試験 装置に導き，そこで脱硝性能を試験した。

試験機関としては，単筒の4サイクルディーゼル機関
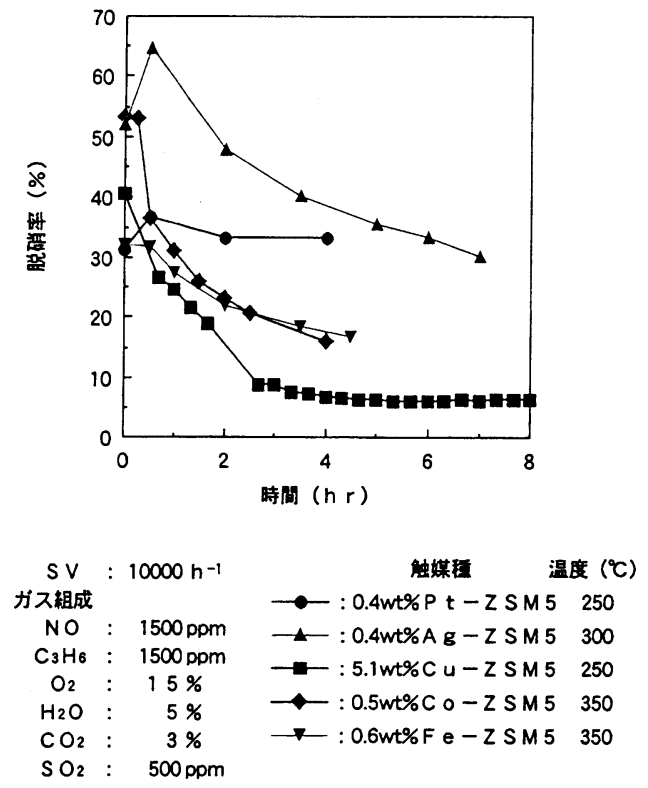

\section{図4 触媒の短期寿命評価（模擬ガス）}

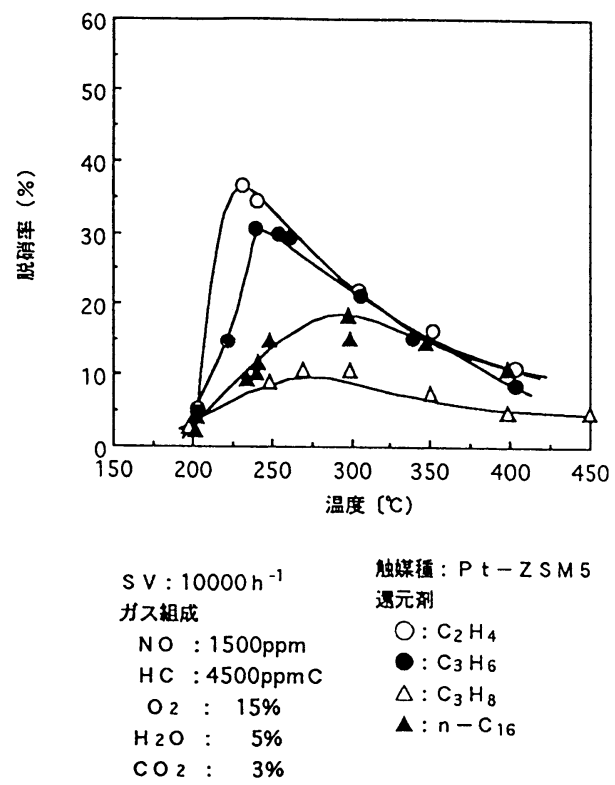

図5＼cjkstart還元剤種による脱硝活性の比較 


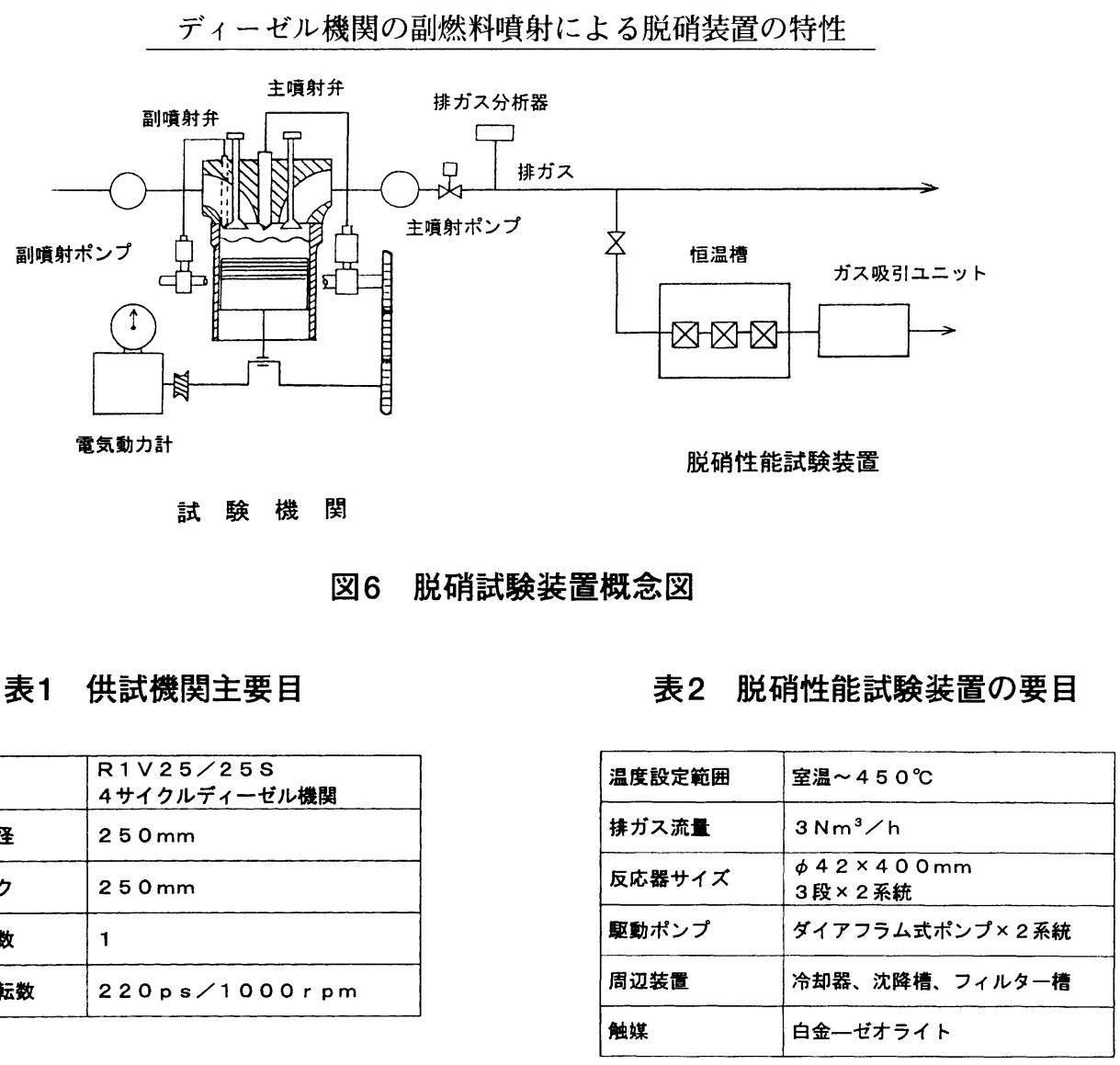

\begin{tabular}{|l|l|}
\hline 型式 & $\begin{array}{l}\text { R1V25/25 S } \\
\text { 4サイクルティーゼル機関 }\end{array}$ \\
\hline シリンダ径 & $250 \mathrm{~mm}$ \\
\hline ストローク & $250 \mathrm{~mm}$ \\
\hline シリンダ数 & 1 \\
\hline 出カ/回転数 & $220 \mathrm{ps} / 1000 \mathrm{r} \mathrm{pm}$ \\
\hline
\end{tabular}

\begin{tabular}{|c|c|}
\hline 温度設定籍囲 & 室温 45 $0^{\circ} \mathrm{C}$ \\
\hline 俫ガス流量 & $3 \mathrm{Nm}^{3} / \mathrm{h}$ \\
\hline 反忘器サイズ & $\begin{array}{l}\phi 42 \times 400 \mathrm{~mm} \\
3 \text { 段 } \times 2 \text { 系統 }\end{array}$ \\
\hline 駆動ポンプ & ダイアフラム式ポンプ× 2 系統 \\
\hline 周辺装置 & 冷却器、沈降槽、フィルター槽 \\
\hline 触媒 & 白金一ゼオライト \\
\hline
\end{tabular}

を用いた。この試験機関には主燃料噴射系とは別に 還元剤としての燃料を噴射する副噴射弁と副噴射ポ ンプを独立して設け，燃料油種，噴射量，噴射時期 を主燃料噴射に関係なく変更することができる，表 1 に試験機関の主要目を示す。

脱硝性能試験装置は, 反応器を内臟した恒温槽 とガスを吸引するためのガス吸引ユニットで構成され ている. 反応器は3段の触媒槽からなり，それぞれ に白金一ゼオライト采触媒が装填してある. 恒温槽と して高温オーブンを用い，触媒槽を通過する排ガス を一定温度にコントロールしている，表2に脱硝性能 試験装置の要目を示す。

3.2 試験方法 本方式は特別に外部から還元 殽を供給するのではなく, エンジンから排出される炭 化水素を積極的に増やして，これを還元㓮として使 用するものである。そこで，まず試験機関を種々の 条件で運転し, さらに副噴射量や噴射時期を変更し 表3 使用燃料油の性状

て排ガス中の炭化水素の量と性状を調査した。次 に，これらの結果をもとに，還元凨として有効と考 えられる条件の排ガスを脱硝性能試験装置に導いて 


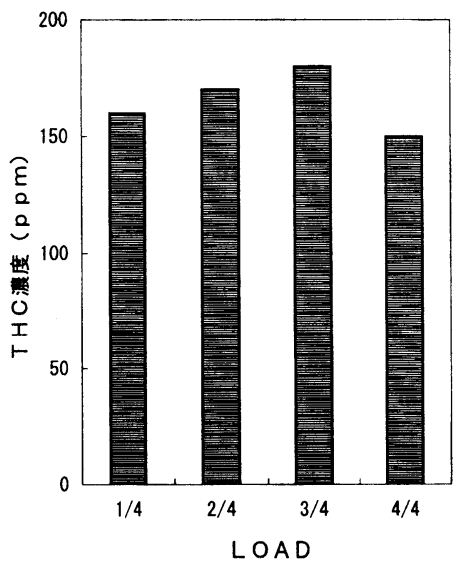

図7 通常運転時の炭化水素濃度

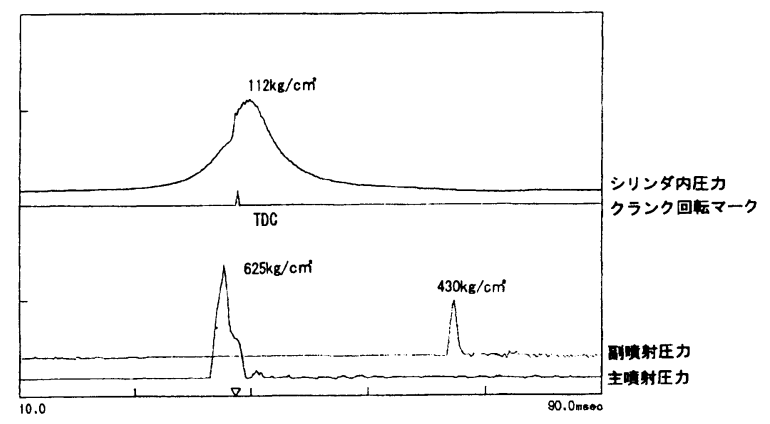

図8 副噴射時のシリンダ内圧力および噴射圧力

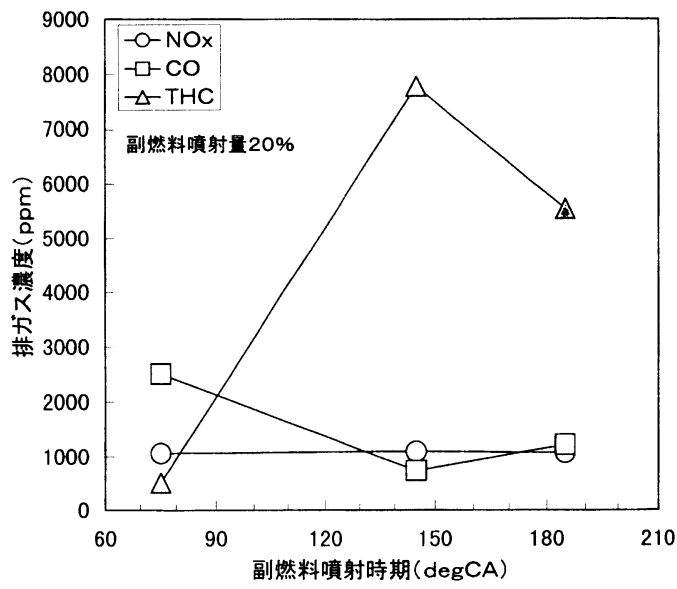

図9副噴射時期と排ガス成分量の関係

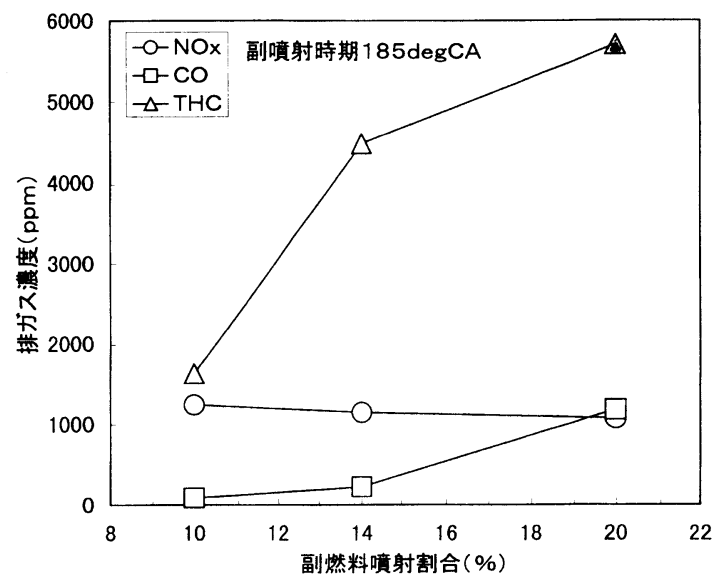

図10 副噴射と排ガス成量分の関係

の条件でも, 機関性能の悪化を考慮するとドラスチ イクな変更は不可能であり, NOx の排出量はせいぜ い300ppm 程度である。そのためガソリンエンジンの ように燃焼排ガス中の炭化水素だけで脱硝を行うこ とは不可能である. 従って, 本方式を用いるために は還元㓮として, 何らかの方法で炭化水素を増加さ せる工夫が必要となる。

4.2 副噴射時の排ガス特性 燃焼ガス中の炭化 水素量を積極的に増加させる方法の一つとして, 燃 料を燃焼室内に追加噴射する副噴射方式を試験し た。図8に副噴射時のシリンダ内圧力および燃料噴 射圧力を示す。これより副噴射による燃料は燃焼が 終了し，排気弁が開いたブローダウン中に供給され るために，燃焼しても筒内圧力にはほとんど影響を 
及ぼさないことが分かる。

図9に副噴射量を一定として噴射時期を変更した 場合の炭化水素，NOx，COの各排出濃度を示す。 炭化水素は排気弁が開く前 (70degCA) に噴射した 場合には燃焼して増加しないが，排気弁が開いた後， ブローダウン中に噴射した場合には約 $6000 \mathrm{ppm}$ とな っている． $6000 \mathrm{ppm}$ 程度であれば $\mathrm{C} / \mathrm{N}$ 比で約 6 程 度となり, 脱硝の還元剤としては十分な炭化水素量 である.ブローダウン中の噴射であっても180degCA よりも150degCA 付近で噴射した方が，炭化水素量 が多く生成されている。これは噴射された時のシリ ンダ内のガス温度が影響しているものと考えられる. 排出NOxに関しては副噴射により増加していない. これには二つの理由が考えられる７0dcgCAの場合 は高温の燃焼ガス中に噴射されるが $\mathrm{O}_{2}$ の少ない状 態で燃焼するのでNOxの生成はほとんどないと考え

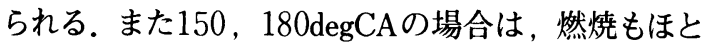
んどなく,さらにNOxが生成される温度以下となって いるためと考えられる．なお，NOx排出量がこの種 の機関としては高い数值 (概ね $1000 \mathrm{ppm}$ ) となってい るが，これは大型 2 サイクルを摸擬した状態で運転 しているためである。COは70degCA 付近で噴射し た場合には低 $\mathrm{O}_{2}$ 雰囲気で燃焼することにより増加す る.

図10は副噴射時期 $185 \mathrm{gegCA}$ 一定で噴射量を変 更した場合の炭化水素, NOx, COの濃度である. 噴射量を増加すると炭化水素濃度は増加する. NOx は副噴射量の供給によりわずかに減少している。こ れは炭化水素による無触媒脱硝作用によるものと考

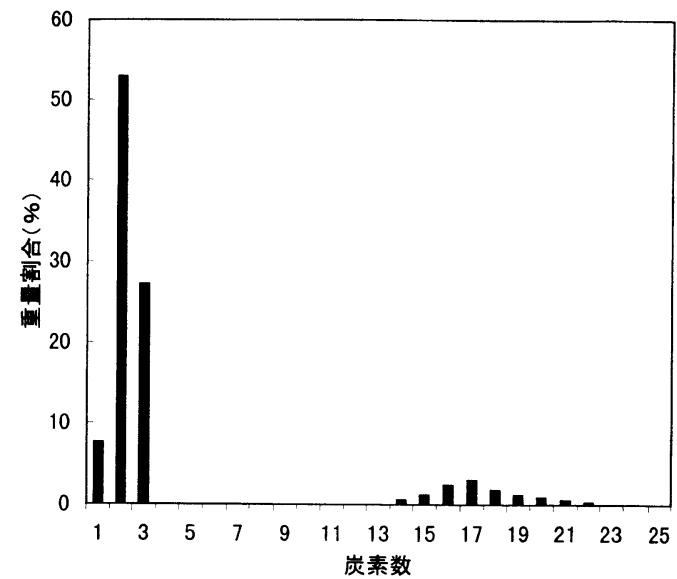

図11 副燃料噴射時の排ガス中の炭素数分布
えられる．COは副噴射量の供給により増加しており， この条件でもわずかではあるが燃焼していることが 分かる。

図11は副噴射時の排気ガスのガスクロマトグラフ による炭素数分析の結果である. 軽質分であるC1〜 C3とA 重油成分であるC 4 C 22 が存在することが分 かる. A 重油の成分にはC1〜C3は含まれておらず， 燃焼室内で分解生成された成分である. エチレン $\left(\mathrm{C}_{2}\right.$ $\left.\mathrm{H}_{4}\right)$ ，およびプロピレン $\left(\mathrm{C}_{3} \mathrm{H}_{6}\right)$ は脱硝還元剤として 有効な成分といわれており，これらの成分を出来る だけ多く生成させる必要がある，そのためには，単 に燃料を蒸発・気化させるだけでなく, 生成に有効 な条件で燃料を噴射することが重要である.

4.3 脱硝性能図12に副噴射を用いた場合の 反応器温度 (オーブン温度; 反応器通過ガス温度) と 脱硝率の関係を示す. 副噴射時の脱硝率 (困中○印) は $250^{\circ} \mathrm{C}$ で最高值を示し，約 $40 \%$ である。この傾向 は併記した気体還元剤であるプロピレン(図中 $\triangle \diamond$ 印)と同じ傾向であり，脱硝率もほぼ同等である，脱 硝率が反応器温度とともに低くなるのは炭化水素を 還元㘊とした脱硝作用では脱硝反応と酸化反応が同 時に進行するためであり, 温度が高くなるほど酸化 反応が強くなり，還元剤が脱硝に有効に利用されな いためである. 図 $13^{1)}$ は筆者らが他の試験装置を用 いて実施したプロピレンを還元凨として用いた場合 の還元剤供給方法による脱硝性能の比較である．脱 硝率は還元剤を反応器の上流から一括注入した場合 では約 30\%と低い值を示すが，還元剤の注入口を 4 個所に分けて分割注入した場合には，約 $70 \%$ と

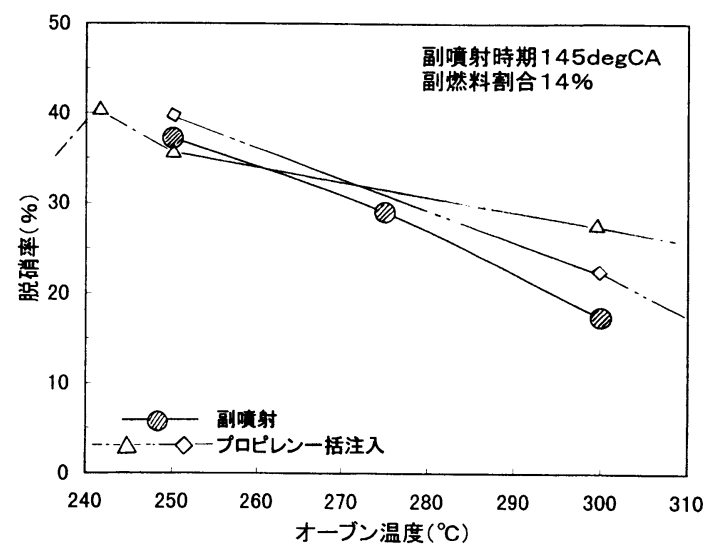

図12 反応器温度と脱硝率の関係 
大幅に向上している. 従って, 副噴射方式の場合も 他の還元剤を追加供給するなどの手段により脱硝率 を向上させることが可能となる。

図 14 は反応器温度を $250^{\circ} \mathrm{C}$ 一定として，5時間運 転した時の脱硝率と反応器通過ガス温度の推移を示 したものである。運転初期には脱硝率が約 $50 \%$ であ るが，時間の経過とともに脱硝率は低下し，約 5 時 間後には約 $40 \%$ となっている。この理由としては試 験初期には上流の触媒槽での酸化反応が低く, 下流 の触媒槽まで還元剤が供給され，脱硝率の高さにつ ながったが, 後半には上流の触媒槽で酸化反応が高 くなり，下流の触媒槽には還元剤が供給されなかっ たためと考えられる。これは各段の触媒槽通過ガス 温度の上昇より良く把握できる。すなわち, 試験初 期には，触媒槽通過ガスは触媒槽を通過するごとに
温度上昇しているが，後半には，上流の触媒槽のみ でガスの温度が上昇し，下流ではほとんど温度上昇 がみられない。これは触媒表面へのカーボンなどの 付着により酸化反応が促進されたものと考えられる. この現象は一時的なもので再生 (約 $350^{\circ} \mathrm{C}$ で一定時 間保持する)により復活することが確認されている.

図15に試験後の触媒端面の状況写真を示す。気 体還元剤であるプロピレンに比べて副噴射方式のも のはカーボンの付着が多くなっている.しかし，その 量は目詰りが生じるほどではない。

図16に各触媒槽の出口における脱硝率を示す。気 体還元剤の一括注入の場合と異なり, 脱硝反応が各 触媒槽で生じていることが分かる.これは炭化水素 系還元剤を用いた脱硝装置では酸化と脱硝反応が 同時に起き，気体還元剤の場合は上流段でほとんど

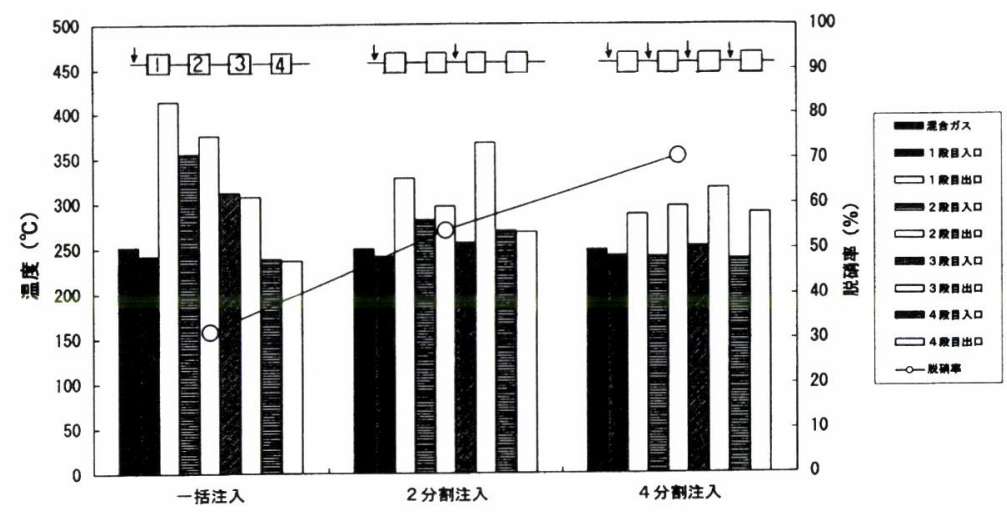

図13還元剤供給方法による脱硝性能の比較（プロピレン）

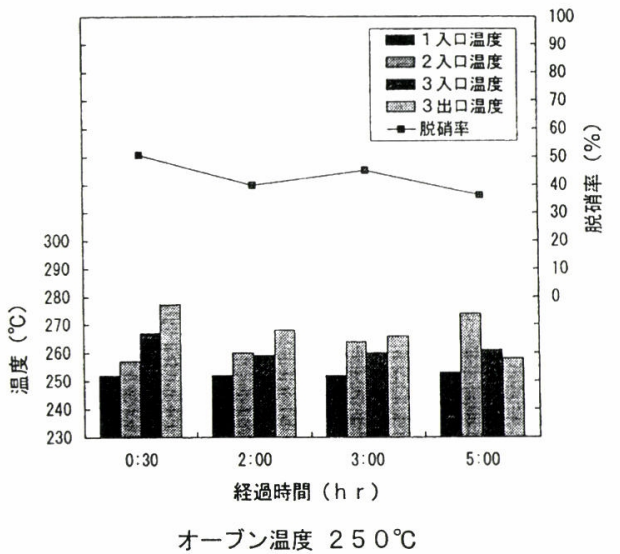

図14 副噴射時の脱硝特性の時間変化と 触媒槽温度変化

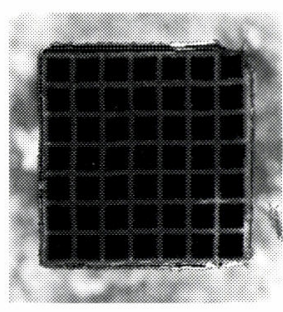

副噴射

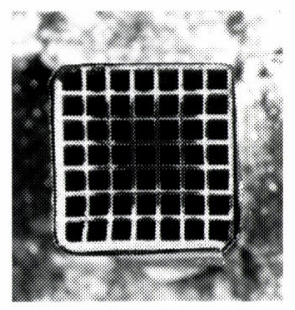

プロピレン
図15 ハニカム触媒端面へのばいじん付着 状況の比較 
の還元剤が消費されるが, 副噴射の場合には, 重質 分が多いため, 酸化反応が抑制され，下流段まで炭 化水素が到達するため考えられる。

図17に脱硝率の向上を意図して下流段に還元剂 を追加供給した場合の脱硝性能の一例を示す. ○印 は2段目と3段目の両方に還元剤を追加供給したも のであり， $\triangle$ 印は3段目のみに追加供給したもので あるが，両者で大きな差異はない。これより，副燃 料方式においては還元剤を追加供給して脱硝率の向

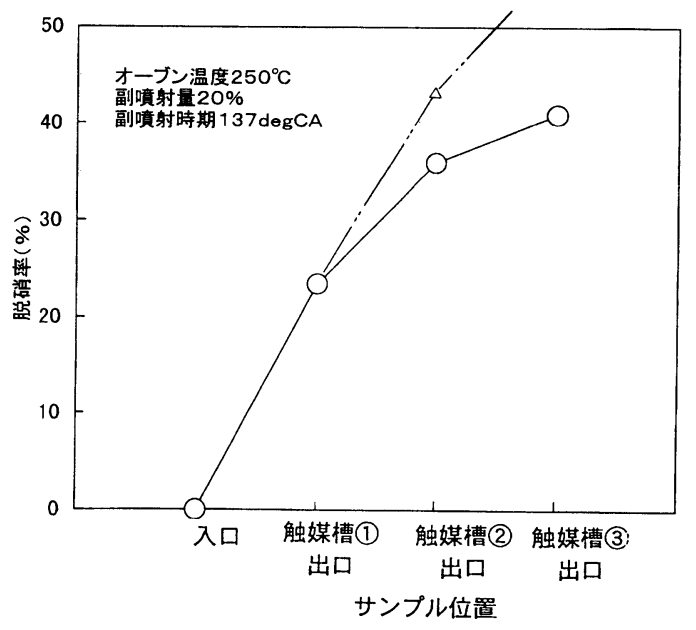

図16 副噴射時の触媒量と脱硝率の関係

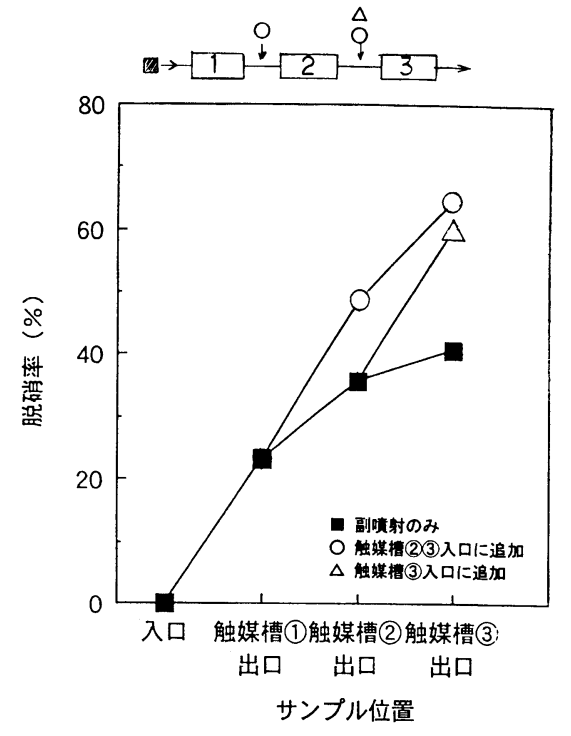

図17還元剤の組み合わせによる 脱硝性能の比較
上を図るには，気体還元剤のように必ずしも全段に 追加供給する必要はなく, 下流のいずれかの1段だ けに追加供給しても同等の効果が期待できることが 分かる.

\section{4.あとがき}

燃料を脱硝装置の還元剤として用いるためのひと つの方法として，エンジンの燃焼室に燃料を副噴射 する方法を試みた。そのために，まず副噴射した場 合の燃焼排ガス性状を調查し，選定した有効な条件 で副燃料を噴射した場合の脱硝性能を試験した。そ の結果, 以下のことが分かった。

(1) 燃料の副噴射によりエンジン排ガスの脱硝に有効 な炭化水素が得られる。

(2) 副噴射の時期は燃焼が終了した(排気弁の開いた BDC近傍) 時期が有効である.

(3) 副噴射時の脱硝率は気体還元剤の一括注入とほ ぼ同程度で約 $40 \%$ である。

(4) 副噴射時の脱硝触媒へのカーボンの付着は目詰 まりを起こす程度ではないが，気体還元剤と比較す ると多い.

副噴射方式は, 反応器の上流からの一括注入な のでそのままでは高い脱硝率が望めないが, 装置が 単純であり, 高い脱硝率を必要としない場合に有効 である. 今後, 他の還元剤の追加噴射など脱硝性能 の向上を罒り, より有効なものとしていきたい.

最後に, 本研究の実験に際し, 富ヶ原勉氏, 瀧 山隆雄氏，木本修一氏の協力を得たことを記し，感 謝の意を表す。

\section{参 考 文 献}

1）中山他 6 名，舶機誌，34-10 (1999-10)，P675

2 ）神社他 8 名, 舶機誌, 34-2，(1999-2)，P169 